\title{
PENGARUH MODEL PEMBELAJARAN DISCOVERY LEARNING TERHADAP PEMAHAMAN KONSEP SISWA KELAS XI PADA MATERI TERMOKIMIA DI MAN 2 KOTA BIMA
}

\author{
Yanti Ramadani, Putri Ayu Mutmainnah, Sry Agustina dan Ruslan \\ Program Studi Pendidikan Kimia STKIP Bima \\ E-mail: yantiraffiahramadani@gmail.com
}

\begin{abstract}
ABSTRAK
Penelitian ini bertujuan untuk mengetahui ada atau tidaknya pengaruh model pembelajaran discovery learning terhadap pemahaman konsep siswa kelas XI IPA pada materi termokimia di MAN 2 Kota Bima. Populasi penelitian ini adalah seluruh siswa kelas XI IPA MAN 2 Kota Bima yang terbagi atas 5 kelas dan terdiri dari 191 orang siswa dengan Kelas XI IPA 3 (kelas kontrol) dan XI IPA 4 (kelas eksperimen, yang menerapkan perlakuan berupa model pembelajaran discovery learning) sebagai sampel setelah sebelumnya pemilihan sampel ini menggunakan teknik non probabillity sampling dengan jenis purposive sampling. Jenis penelitian ini adalah quaisi experiment dengan posttest only control group design sebagai rancangannya. Pengaruh model pembelajaran discovery learning ditunjukkan oleh nilai Asym Sig. (2-tailed) dari uji Mann Whitney berdasarkan nilai posttest pemahaman konsep siswa antara kelas kontrol dan kelas eksperimen. Hasil penelitian menunjukkan bahwa nilai Asym Sig. (2-tailed) > 0,05 yakni sebesar 0,096, hal ini berarti tidak terdapat perbedaan rata-rata pemahaman konsep siswa kelas eksperimen dengan kelas kontrol pada materi termokimia. Artinya, dapat disimpulkan bahwa tidak terdapat pengaruh model pembelajaran discovery learning terhadap pemahaman konsep siswa kelas XI pada materi termokimia di MAN 2 Kota Bima.
\end{abstract}

Kata Kunci : Model Pembelajaran Discovery Learning, Pamahaman Konsep, dan Termokimia

\section{PENDAHULUAN}

Kurikulum yang berlaku di Indonesia saat ini adalah kurikulum 2013, dimana kurikulum ini merupakan perbaikan dari kurikulum 2006 atau lebih dikenal dengan sebutan KTSP (Kurikulum Tingkat Satuan Pendidikan). Pembelajaran yang diharapkan dalam Kurikulum 2013 adalah pembelajaran yang memperkaya pengalaman belajar siswa dengan menggunakan pendekatan berbasis keilmuan/saintifik. Tentu saja, implementasi dari pendekatan saintifik dalam pembelajaran perlu diperkuat dengan diterapkannya model pembelajaran. Model pembelajaran sebagaimana dimaksud pada Permendikbud Nomor 103 Tahun 2014 dan Permendibud Nomor 22 Tahun 2016 dalam Direktorat Pembinaan SMA (2017) adalah model pembelajaran yang menonjolkan aktivitas dan kreativitas, menginspirasi, menyenangkan dan berprakarsa, berpusat pada siswa, otentik, kontekstual, dan bermakna bagi kehidupan siswa sehari-hari.

Model pembelajaran yang terdapat pada kurikulum 2013 antara lain ialah pembelajaran berbasis masalah (Problem Based Leraning), pembelajaran berbasis proyek (Projek Based Learning), dan pembelajaran penemuan (Discovery Learning). Dari ketiga model pembelajaran tersebut guru dapat memilih salah satu model pembelajaran untuk diterapkannya di dalam kelas. Dalam pemilihan model pembelajaran, guru harus memperhatikan faktor yang dapat mendukung kelancaran dan ketercapaian tujuan pembelajaran. Adapun faktor yang dimaksud antara lain karakteristik siswa, sarana dan prasarana, media pembelajaran, dan karakteristik materi pembelajaran. 
Menurut Kean dan Middlecamp (1985) dalam Cahyarini dkk (2016) ilmu kimia memiliki beberapa karakteristik yaitu sebagian besar konsepnya bersifat abstrak, konsepkonsepnya merupakan penyederhanaan dari keadaan sebenarnya, dan konsep-konsepnya saling berkaitan dan berurutan. Supardi dan Putri (2010) menerangkan bahwa materi kimia diklasifikasikan sebagai mata pelajaran yang sulit dipahami bagi sebagian siswa SMA. Hal ini dipengaruhi oleh banyak faktor, salah satunya adalah kurangnya pemahaman siswa terhadap konsep-konsep kimia (Nazar dkk., 2010). Salah satu konsep kimia yang paling sulit dipahami oleh siswa pada umumnya adalah termokimia. Termokimia memiliki karakteristik pemahaman konsep yang cukup tinggi, sehingga dalam hal ini siswa harus memiliki pemahaman ekstra agar dapat memahami konsep termokimia dengan benar.

Berdasarkan hasil observasi yang dilakukan pada 20 Mei 2019, penyusunan silabus dan RPP sudah sesuai dengan kurikulum 2013 namun RPP yang disusun tidak diimplemntasi pada saat kegiatan belajar mengajar. Hal ini diperkuat oleh hasil wawancara peneliti dengan beberapa siswa kelas XI IPA MAN 2 Kota Bima tahun pelajaran 2018/2019, siswa mengatakan bahwa pembelajaran hanya berpusat pada guru dan siswa hanya mendengarkan penjelaskan dari guru dan diakhir pertemuan selalu memberikan latihan dan tugas. Hal ini berarti pembelajaran masih bersifat satu arah dengan kata lain guru masih menggunakan metode ceramah. Pembelajaran yang seperti ini mengakibatkan banyak siswa yang belum mencapai kriteria ketuntasan minimal (KKM) yang ditetapkan yakni 75 . Selain itu daya ingat siswa tentang materi pelajaran yang diajarkan tidak bertahan lama.

Pembelajaran yang berpusat pada guru atau pembelajaran yang terlalu teoritis menyebabkan siswa sulit memahami bahan ajar kimia secara komprehensif. Oleh karena itu, siswa cenderung menghafal tanpa memahami materi dasarnya. Akibatnya, skema pemikiran siswa terpotong-potong dan tidak terjadi pemahaman secara utuh (Azzahra, 2010). Berdasarkan hal tersebut, maka peneliti mencoba mencarikan solusi untuk siswa terhadap pemahaman konsep pada materi termokimia dengan cara menerapkan model pembelajaran discovery learning. Model discovery learning adalah salah satu model pembelajaran yang bertujuan untuk meningkatkan sikap aktif dan kreatif siswa dalam proses pembelajaran, sehingga siswa dapat terlatih dalam menemukan suatu konsep secara mandiri dengan tetap dibantu oleh guru dan dapat meningkatkan pemahama konsep siswa (Kartika, 2017). Penelitian menggunakan model pembelajaran discovery learning telah dilakukan oleh peneliti lain sebelumuya seperti Setiawan (2018), hasil penelitiannya menunnjukkan discovery learning berpengaruh terhadap pemahaman konsep matematis siswa. Selanjutnya Widiadnyana, dkk (2014) juga menyimpulkan bahwa model DL juga dapat mempengaruhi pemahaman konsep dan sikap ilmiah siswa dalam pembelajaran.

Berdasarkan uraian di atas, pembelajaran menggunakan model discovery learning diharapkan berpengaruh terhadap pemahaman konsep siswa, oleh sebab itu penting bagi peneliti untuk melakukan penelitian dengan judul "Pengaruh Model Pembelajaran Discovery Learning Terhadap Pemahaman Konsep Siswa Kelas XI Pada Materi Termokimia Di MAN 2 Kota Bima Tahun Pelajaran 2019/2020".

Berdasarkan latar belakang masalah tersebut, peneliti merumuskan masalah sebagai berikut "Apakah terdapat pengaruh model pembelajaran discovery learning terhadap pemahaman konsep siswa kelas XI pada materi termokimia di MAN 2 Kota Bima?". Tujuan penelitian ini adalah untuk mengetahui ada atau tidaknya pengaruh model discovery 
learning terhadap pemahaman konsep siswa kelas XI pada materi termokimia di MAN 2 Kota Bima.

\section{METODE}

Jenis penelitian ini adalah penelitian eksperimen, berupa quasi-experiment design dengan jenis rancangan yang digunakan adalah posttest only group design. Adapun rancangan yang dimaksud dapat dilihat pada tabel berikut :

Tabel 1. Posttest Only Group Design

\begin{tabular}{|c|c|c|}
\hline Kelas & Treatment & Post-test \\
\hline Eksperimen & $\mathrm{X}$ & $\mathrm{O}_{2}$ \\
\hline Kontrol & - & $\mathrm{O}_{4}$ \\
\hline
\end{tabular}

Keterangan:

$\mathrm{X}$ : Pemberian perlakuan pada kelas eksperimen berupa model pembelajaran discovery learning.

$\mathrm{O}_{2}$ : Hasil post-test pada kelas eksperimen.

04: Hasil post-test pada kelas kontrol (Sugiyono, 2010).

Populasi pada penelitian ini adalah seluruh siswa kelas XI IPA MAN 2 Kota Bima tahun pelajaran 2019/2020 yang terdiri dari 5 kelas yang berjumlah 191 siswa. Sampel yang digunakan pada penelitian ini adalah sebanyak 2 kelas, pengambilan sampel menggunakan teknik non probabillity sampling dengan jenis puposive sampling. Pada penelitan ini instrumen yang digunakan adalah instrumen jenis tes yang berupa soal non objektif berbentuk uraian/essay. Jumlah soal yang digunakan adalah 8 butir soal.

Pada penelitian ini diawali dengan pemberian perlakuan di kelas eksperimen sedangkan di kelas kontrol tidak. Proses pembelajaran pada kedua kelas tersebut disesuaikan dengan jadwal mata pelajaran Kimia yang menjadi sampel di MAN 2 Kota Bima. Setelah poses pembelajaran baik di kelas eksperimen maupun kelas kontrol selesai lalu langkah selanjutnya adalah memberikan posttest pada kedua kelas tersebut. Bentuk soal pada posttest yang digunakan berupa uraian dengan bentuk uraian non objektif sehingga teknik penskoran yang digunakan adalah rentangan skor. Adapun tingkatan tes yang digunakan adalah C2 sampai dengan C5 berdasarkan taksonomi Bloom. Sebelumnya soal tersebut telah divalidasi oleh ahli yakni 1 Dosen Pendidikan Kimia STKIP Bima dan 1 guru mata pelajaran kimia kelas XI IPA MAN 2 Kota Bima. Langkah terakkhir ialah mengumlpkan data posttest dan menganalisis untuk mengetahui apakah terdapat pengaruh model pembelajaran discovery learning terhadap pemahaman konsep siswa kelas XI IPA pada materi termokimia di MAN 2 Kota Bima. Adapun yang bertugas untuk menguji validitas soal posttest adalah Ibu Putri Ayu Mutmainah, M.Pd. dengan Ibu Nurul Najmun, S.Pd. sedangakan yang memberikan perlakuan, posttest, serta menganalisis data posttest dilakukan oleh peneliti sendiri.

Analisis data dilakukan untuk memecahkan permasalahan pada rumusan masalah dan menguji hipotesis penelitian yang diajukan, untuk mempermudah dalam melakukan pengolahan data, semua pengujian statistik pada penelitian ini dilakukan dengan menggunakan bantuan software SPSS versi 22 for windows. Adapun analisis data yang dilakukan adalah uji prasyarat yang terdiri dari uji normalitas menggunakan Shapiro Wilk 
Test dan uji homogenitas menggunakan homogenity of variance test pada One-Way Anova, serta uji hipotesis. Hipotesis yang diajukan pada penelitian ini adalah $\mathrm{H}_{0}$ yaitu tidak ada perbedaan rata-rata pemahaman konsep siswa kelas eksperimen dengan kelas kontrol pada materi termokimia dan $\mathrm{H}_{\mathrm{a}}$ yaitu ada perbedaan rata-rata pemahaman konsep siswa kelas eksperimen dengan kelas kontrol pada materi termokimia.

\section{HASIL}

Data yang digunakan dalam penelitian ini berupa tes. Oleh karena yang diukur pada penelitian ini adalah pemahaman konsep siswa maka jenis tes yang digunakan yaitu tes non objektif berupa tes uraian non objektif sebanyak 8 butir soal. Soal ini diberikan kepada siswa yang menjadi sampel penelitian di kelas XI IPA 4 (kelas eksperimen) dan kelas XI IPA 3 (kelas kontrol). Sebelum soal diberikan, terlebih dahulu soal diuji kavalidannya.

Nilai pemahaman konsep siswa di kelas eksperimen maupun di kelas kontrol dapat dilihat pada tabel berikut:

Tabel 1. Nilai Pemusatan dan Penyebaran Pemahaman Konsep Siswa Berdasarkan Postest

\begin{tabular}{|l|c|c|c|c|c|}
\hline \multicolumn{7}{|c|}{ Descriptive Statistics } \\
\hline & $\mathrm{N}$ & Min & Max & Mean & Std. Deviation \\
\hline Kelas Ekperimen & 37 & 42 & 100 & 81,97 & 20,318 \\
\hline kelas kontrol & 34 & 31 & 100 & 75,12 & 18,964 \\
\hline
\end{tabular}

Berdasarkan tabel 1 dapat diketahui bahwa pada kelas eksperimen nilai terendah siswa sebesar 42, nilai tertinggi sebesar 100, nilai rata-rata sebesar 81,97 dan simpangan baku sebesar 20,318. Sedangkan pada kelas kontrol nilai terendah siswa sebesar 31, nilai tertinggi sebesar 100, nilai rata-rata sebesar 75,12 dan simpangan baku sebesar 18,964.

Pengujian normaliras posttest dari kelas eksperimen dan kelas kontrol didapatkan hasil sebagai berikut:

Tabel 2. Hasil Uji Normalitas Kelas Eksperimen dan Kelas Kontrol Berdasarkan Nilai Posttest Siswa

\begin{tabular}{|l|c|c|c|c|}
\hline \multirow{2}{*}{$\begin{array}{c}\text { Pemahaman } \\
\text { Konsep }\end{array}$} & \multicolumn{3}{|c|}{ Shapiro-Wilk } & \multirow{2}{*}{ Keterangan } \\
\cline { 2 - 4 } & Statistic & df & sig & \\
\hline Eksperimen & 0,779 & 37 & 0,000 & Tidak Normal \\
\hline Kontrol & 0,943 & 34 & 0,077 & Normal \\
\hline
\end{tabular}

Berdasarkan tabel di atas, dapat disimpulkan bahwa data posttest kelas eksperimen adalah tidak normal karena nilai sig $<0,05$. Sedangkan pada kelas kontrol data berdistribusi normal karena nilai sig $>0,05$. Sedangkan pengujian homogenitas yang dilakukan pada kelas eksperimen dan kelas kontrol berdasarkan data posttest. Tampilan hasil uji homogenitas dapat dilihat pada tabel 3 berikut: 
Tabel 3. Uji Homogenitas Kelas Eksperimen dan Kelas Kontrol Berdasarkan Nilai Posttest

\begin{tabular}{|r|r|r|c|}
\hline \multicolumn{5}{|c|}{ Test of Homogeneity of Variances } \\
\hline pemahaman konsep siswa \\
\hline Levene Statistic & df1 & df2 & Sig. \\
\hline 715 & 1 & 69 &, 401 \\
\hline
\end{tabular}

Berdasarkan tabel di atas, dapat disimpulkan bahwa data dari kedua kelas memiliki variansi yang homogen karena nilai signifikan lebih besar dari 0,05. Setelah dilakukan uji prasyarat yaitu uji normalitas dan homogenitas berdasarkan data posttest pada kelas eksperimen maupun kelas kontrol, maka selanjutnya dilakukan uji hipotesis. Uji hipotesis dilakukan menggunakan uji Mann Whitney $U$ dengan bantuan SPSS versi 22. Pengujian hipotesis menggunakan uji ini dilakukan karena data tidak terdistribusi normal walaupun sampel mempunyai variansi yang homogen. Hasil uji hipotesis yang dilakukan dapat dilihat pada tabel berikut:

Tabel 4. Hasil Uji Hipotesis Berdasarkan Data Pretest Pada Kelas Eksperimen Dan Kelas Kontrol

Test Statistics ${ }^{\mathrm{a}}$

\begin{tabular}{|l|r|}
\hline & Pemahaman Konsep Siswa \\
\hline Mann-Whitney U & 485,000 \\
Wilcoxon W & 1080,000 \\
Z & $-1,665$ \\
Asymp. Sig. (2-tailed) &, 096 \\
\hline
\end{tabular}

${ }^{a}$ Grouping Variable: Kelas Eksperimen dan Kelas Kontrol

Berdasarkan tabel 4 maka dapat dikatakan bahwa $\mathrm{H}_{0}$ yaitu tidak ada perbedaan ratarata pemahaman konsep siswa antara kelas eksperimen dan kelas kontrol pada materi termokimia diterima karena nilai Asym sig. (2-tailed) $>0,05$. Artinya tidak ada pengaruh model pembelajaran discovery learning terhadap pemahaman konsep siswa kelas XI IPA pada materi termokimia di MAN 2 Kota Bima.

\section{PEMBAHASAN}

Setelah proses pembelajaran pada kelas eksperimen dan kelas kontrol telah dilaksanakan, selanjutnya siswa diberikan posttest. Posttest dilakukan pada pertemuan terakhir dari masing-masing kelas. Berdasarkan hasil penelitian yang dilakukan peneliti di MAN 2 Kota Bima, diperoleh perhitungan rata-rata pemahaman konsep termokimia kelas XI IPA 4 (kelas eksperimen) dengan menerapkan model pembelajaran discovery learning berdasarkan hasil posttest adalah 81,97 . Sedangkan nilai rata-rata pemahaman konsep termokimia kelas XI IPA 3 (kelas kontrol) dengan menerapkan model pengajaran langsung berdasarkan hasil | posttest adalah 75,12.

Setelah dilakukan pengolahan data secara statistik yaitu dengan melakukan uji prasyarat yang terdiri dari uji normalitas dan uji homogentitas, didapatkan hasil pengujian normalitas menunjukkan bahwa data posttest dari kelas eksperimen berditribusi tidak normal sedangkan kelas kontrol berdistribusi normal, pada uji homogenitas pada kedua 
kelas didapatkan hasil sampel memiliki variansi homogen. Selanjutnya dilakukan uji hipotesis, uji hipotesis dilakukan menggunakan uji Mann Whitney karena data kelas eksperimen berdistribusi tidak normal meskipun kelas kontrol berdistribusi normal dan sampel pada kedua kelas memiliki variansi yang homogen. Adapun hasil uji hipotesis yang dilakukan maka diperoleh nilai Asym Sig. sebesar ,096. Oleh karena nilai hasil uji hipotesis lebih besar daripada 0,05 maka $\mathrm{H}_{0}$ diterima yakni hipotesis yang mengatakan bahwa tidak ada perbedaan rata-rata pemahaman konsep siswa antara kelas eksperimen dan kelas kontrol pada materi termokimia. Oleh karena demikian, $\mathrm{H}_{\mathrm{a}}$ ditolak yaitu ada perbedaan ratarata pemahaman konsep siswa antara kelas eksperimen dan kelas kontrol pada materi termokimia, artinya tidak ada pengaruh model pembelajaran discovery learning terhadap pemahamn konsep siswa kelas XI IPA pada materi termokimia di MAN 2 Kota Bima.

Penerapan discovery learning menggunakan metode diskusi harusnya bisa membuat siswa akan lebih mengingat apa yang didiskusikan daripada menerima penjelasan dari guru, namun berdasarkan hasil penelitian yang dilakukan ternyata tidak terdapat pengaruh model pembelajaran discovery learning terhadap pemahaman konsep siswa kelas XI pada materi termokimia di MAN 2 Kota Bima. Hal ini dipengaruhi olehh beberapa faktor, diantaranya adalah sarana dan prasarana yang minim, alokasi waktu yang kurang, dan siswa tidak terbiasa dengan model discovery learning sehingga siswa kesulitan selama melakukan proses pembelajaran dengan model pembelajaran tersebut. Hal ini sejalan denga yang disampaikan oleh Kurniasih dan Berlin (2014) tentang kelemahan model pembelejaran discovery learning antara lain: (1) dibutuhkan persiapan media yang lebih optimal; (2) harapan-harapan yang terkandung dalam model ini dapat buyar berhadapan dengan siswa dan guru yang telah terbiasa dengan cara-cara belajar yang lama; dan (3) dibutuhkan waktu yang lama untuk siswa menemukan teori baru.

Hal ini juga sejalan dengan hasil penelitian oleh peneliti sebelumnya yang menggunakan model discovery learning seperti oleh Nurrohmah (2018) menyimpulkan bahwa model pembelajaran discoveri learning tidak berpengaruh terhadap pemahaman konsep matematis siswa.

\section{KESIMPULAN}

Penelitian ini menghasilkan temuan, bahwa tidak terdapat pengaruh model pembelajaran discovery learning terhadap pemahaman konsep siswa kelas XI IPA pada materi termokimia di MAN 2 Kota Bima. Berdasarkan penelitian yang telah dilakukan, dapat diajukan beberapa saran; (1) dalam penerapan model discovery learning, hendaknya dilakukan dengan sungguh-sungguh dan sesuai prosedur serta adanya persiapan guru dan siswa untuk memperoleh hasil yang optimal; (2) pihak sekolah hendaknya dapat mengakomodasi dan memfasilitasi untuk optimalisasi implementasi discovery learning; (3) pihak pemerintah dapat mengupayakan dalam penyediaan fasilitas dan sarana pembelajaran IPA khususnya kimia di sekolah; dan (4) peneliti selanjutnya diharapkan dapat membagi waktu dengan baik, mengingat model pembelajaran discovery learning membutuhkan waktu yang tidak sedikit, serta untuk dapat melakukan penelitian kembali secara mendalam tentang pengaruh model pembelajaran discovery learning terhadap pemahaman konsep siswa pada materi termokimia yang nantinya dapat dijadikan referensi pembanding dengan penelitian yang telah dilakukan. 


\section{DAFTAR PUSTAKA}

Azzahra, S. F. (2010). Pengaruh Metode Eksperimen Terhadap Hasil Belajar Siswa Pada Konsep Laju Reaksi. (Skripsi). Universitas Islam Negeri Syarif Hidayatullah, Jakarta.

Cahyarini, A., Rahayu, S., dan Yahmin. (2016). Pengaruh Model Pembelajaran Learning Cycle 5e Terhadap Penguasaan Konsep Siswa Pada Materi Asam Basa. Prosiding Seminar Nasional II Tah un 2016, Kerjasama Prodi Pendidikan Biologi FKIP dengan Pusat Studi Lingkungan dan Kependudukan (PSLK) Universitas Muhammadiyah Malang Malang (hlm. 607-615).

Direktorat Pembinaan SMA. (2017). Model-model Pembelajaran. Jakarta: Dikdasnas.

Putri Ika, Ayu Mutmainnah, Putri, Sry Agustina, Ruslan, (2018). Pengaruh Model Pembelajaran Langsung Terhadap Hasil Belajar Siswa Ipa Terpadu Pada Siswa Kelas Vii Smp Negeri 2 Ambalawi Tahun Pelajaran 2018/2019. Jurnal Redoks: Jurnal Pendidikan Kimia Dan Ilmu Kimia, 1 (1), 23-29.

Jauhar, M. (2011). Implementasi Paikem dari Behavioristiksampai Konstrukti-vistik. Jakarta: Prestasi PustakaPublisher.

Kartika, E. R. (2017). Penerapan model discovery learning dalam meningkatkan kemampuan berpikir orisinil pada materi larutan elektrolit dan non elektrolit. (Skripsi). Universitas Lampung, Bandar Lampung.

Nazar, M., Sulastri, S., Winarni, S., dan Fitriana, R. (2010). Identifikasi Miskonsepsi Siswa SMA Pada Konsep Faktor-faktor Yang Mempengaruhi Laju Reaksi. Jurnal Biologi Edukasi, 2 (3), hal. 49-53.

Setiawan, W. (2018). Pengaruh Model Discovery Learning Terhadap Pemahaman Matematis Siswa (Studi Pada Siswa Kelas VII Semester Genap SMP Negeri 17 Pesawaran Tahun Pelajaran 2016/2017). (Skripsi). Universitas Lampung, Bandar Lampung.

Slameto, U. (2016). Belajar dan Faktor-Faktor yang Mempengaruhi. Jakarta:Rineka Cipta.

Sugiyono, (2010). Metode Penelitian Pendidikan Pendekatan Kuantitatif, Kualitatif, dan R\&D. Bandung: Alfabeta.

Supardi, K. I., dan Putri, I. R. (2010). Pengaruh Penggunaan Artikel Kimia Dari Internet Pada Model Pembelajaran Crative Problem Solving Terhadap Hasil Belajar Kimia Siswa SMA. Jurnal Inovasi Pendidikan Kimia, 4 (1).

Tim Penyusun. (2014). Pedoman Mata Pelajaran Kimia. Jakarta: Kemendikbud.

Widiadnyana I W., Sadia I W., dan Suastra I W. Pengaruh Model Discovery Learning Terhadap Pemahaman Konsep IPA dan Sikap Ilmiah Siswa SMP. e-Journal Program Pascasarjana Universitas Pendidikan Ganesha Program Studi IPA, 4.

Rijal, C. (2018). Pengaruh Model Discovery Learning Terhadap Keterampilan Proses Sains Siswa Pada Materi Larutan Asam Dan Basa Di Kelas Xi Man 2 Aceh Utara. (Skripsi). Universitas Islam Negeri Ar-Raniry Banda Aceh 